\title{
The Impact of Tourism on Village Society
}

\author{
Filma Festivalia ${ }^{* 1}$, Mimi Enggriani ${ }^{2}$, Purwanti Dyah Pramanik ${ }^{3}$ \\ 1 Sekolah Tinggi Pariwisata Trisakti \\ 2 Sekolah Tinggi Pariwisata Trisakti \\ 3 Sekolah Tinggi Pariwisata Trisakti \\ *purwanti@stptrisakti.ac.id
}

\begin{abstract}
The research aimed to analyze "The Impact of Tourism on Village Society". The methodology of the study was quantitative research and descriptive analysis. The research was located in Sumurugul village. Respondents of this research were 92 residents. The data was collected by using convenience sampling. The data was analyzed by using validity and reliability test, frequency, and descriptive (mean) analysis. The study found that there is the positive impact of tourism on village society in Sumurugul in the point of economics, social, and environment aspect. The implication of this study showed that tourism should be one of the alternatives to develop a village.
\end{abstract}

Keywords: Impact, Tourism, Village, Society. 


\section{A. Introduction}

Every development of a tourist destination area must be able to provide welfare to local people who are around the tourist area. Well-being includes physical and mental welfare. Physical welfare includes being able to meet economic needs due to increase income after the existence of tourism activities in the region. Mental welfare covers feelings of pleasure and happiness when developing tourism activities in the region. Local people will happy if community around the tourist destination is treated as a subject rather than an object in these tourist activities. How to treat local people as subjects? It's simple such as considering local people opinion in various decisions making, and involving them in developing a tourist destination.

Purwakarta district is now establishing tourism sectors actively. The local government is developing Wanayasa as tourism destination. Sumurugul village is one of the villages in the Wanayasa sub-district which is currently developing into a tourist and recreational area, such as bicycle track tours and other natural attractions. The location of the Sumurugul village is right on the border with Mount Burangrang. Its scenery is natural and the air is cool $(20$ - 30 degrees Celsius) so that the village of Sumurugul has good tourism potential so many tourists are interested in doing tourism activities in the village. This study is going to analyze "The Impact of Tourism on Village Society".

\section{B. Literature Review}

Since the tourism destination are developed, the community around the destination welcome it (Hariyana et al., 2015) if it's able to increase their economic level (Aldilla, 2012) and so their quality of life (Hanafiah et al.,2016). Tourism destination development in the point of economic's view is able to create job opportunities (Hamzah et al., 2018) such as amenities providers (catering, entertainment providers, local transportation providers), as accommodation providers such as home stay providers, as tour guides on permanent attractions such as sites, historic buildings, natural wonders, and organizers of tourism activities both outdoor and indoor (Reisinger, Yvette, 2001). Another positive impact of tourism development that it could increase the chance for local community to have better income by selling the handicraft they create (Ningsih et al., 2018) such as sarung tenun Samarinda (Sudarmayasa et al., 2019), and so drives entrepreneurship activities (Subchan, 2014). Not only that, since infrastructure is being better, the transportation is available if tourism destination is developed (Li, S.N., 2017). The tourism sector is an effective sector in addressing the need to increase economic added value in tackling poverty (pro-poor) and job creation (projob) (Vitriani et al., 2018). Tourism development has to drive local income (Wang, 2015). Unfortunately, the rate of goods and services tend to be higher while tourism activity is completed in a certain area (Li, S.N., 2017; P.D. Pramanik \& Ingkadijaya, 2017). And the development of a tourist destination is predicted to create jobs but local people 
often only work as unskilled workers such as security officers, construction workers, or carpenters. Moreover, even tourism is able to generate income for local community but its income is very small (Pratt, 2015).

Tourism produced socially inequitable. Socially inequitable should be minimize such as tourism development should protect local and national culture, and so improve social and individual well-being (Choi, 2005). Tourism impacts on social aspect are both positive and negative sides. The positive impacts are improvement in standard of living, cleaner communal area, and an improvement of public service (Asyraf, 2017). The negative impacts are the loss of traditional values, an increase in crime, prostitution, and a decrease in resident hospitality (Garau-Vadell, et al., 2018).

Tourism is also produced environmentally disruptive growth. Preserving environment is one of domain in sustainable tourism. The quality of the nature could deteriorate as the result of human activities at tourism destination (Asyraf, 2017). Tourism development has to reduce the negative impacts on the environment (Choi, 2005). It could be minimized by implementing education and training program, and monitor its implementation for residents and visitors as well (Choi, 2005). The example of positive tourism impact on environment is improving the awareness to preserve the environment. But the negative impact are an increase of pollution levels on air, water, and noise (Garau-Vadell et al., 2018).

Purwakarta district is now establishing tourism sectors actively. The local government is developing Wanayasa as tourism destination. It's categorized as special attraction (Inskeep, 1991 in Swarbrooke, 2002.). Special attraction is tourist destinations made by humans such as theme parks, or museum. A tourist destination can be attracted the attention of tourist arrivals when all the elements of attraction have been built and managed well (Ritchie and Crough, 2003). The tourism destination which is managed well will sustain. Sustainable tourism destination can be reached if it contributes better quality of life now and the future (Postma, 2017) as the impact of tourism destination development.

\section{Research Methodology}

The research method is quantitative descriptive. The unit of analysis is 92 respondents from Sumurugul Village. The respondents were chosen by convenience sampling. The research variable is respondents' perception of tourism impacts on economics, social, and environmental aspects. The research aimed to analyze "Village community perception of tourism impacts". The questionnaire is divided into two parts. The first part asked about respondents profiles which consist of gender, age, job, educational background, and income. Then the second part consists of 6(six) statements of economics aspect; 6(six) statements of social aspects; and 8(eight) statements of environmental aspect. Measurement of the research used a 5-point Likert scale, where number 1 shows the perception of strongly disagree, number 2 shows the perception of disagree, 
number 3 shows the perception neutral, number 4 shows the perception of agree , and number 4 shows the perception of strongly agree. The research was analyzed by validity and reliability test, frequency and descriptive (mean) analysis. For mean analysis, table 1 shows mean interpretation. The location of the study was conducted in the village of Sumurugul, Wanayasa sub-district, Purwakarta, West Java. The research period is from March 2019 until September 2019.

Table 1. Mean Interpretation

\begin{tabular}{ll}
\hline Range & Interpretaion \\
\hline $1.00-1.20$ & Least affected \\
$1.21-2.40$ & Less affected \\
$2.41-3.60$ & Neutral \\
$3.61-4.80$ & Affected \\
$4.81-5.00$ & Strongly affected \\
\hline
\end{tabular}

\section{Result}

The test consisted of validity, reliability, frequency, and descriptive (mean) analysis.

\section{Validity Analysis}

The number of respondents was 92 people. To calculate the validity using table $\mathrm{r}$ : the number of respondents $-2=90$, in table $\mathrm{r}$ at a significance of 0.05 , a value of 0.205 is obtained. Therefore all statements that have a value above 0.205 are considered valid. Thus economic statements of "The development of the Wanayana tourism destination provides job opportunity for Sumurugul village society" is 0.425 (> r-table); "The development of Wanayana tourism destination increases Sumurugul society income" is 0.763 ( $>$ r-table); "The development of the Wanayana tourism destination provides an opportunity for the community to sell their creations" is 0.742 ( $>$ r-table); "The development of Wanayana tourism destination improves transportation facilities" is 0.465 ( $>$ r-table); "The development of the Wanayana tourism destination makes the prices of goods and services cheaper" is 0.249 ( $>$ r-table); "The development of the Wanayana tourism destination has attracted tourists to visit the Sumurugul village" is 0.149 $(<\mathrm{r}$-table). The result is shown that the statement "The development of the Wanayana tourism destination has attracted tourists to visit the Sumurugul village" isn't valid. That statement was removed from the questionnaire.

\section{Reliability Analysis}

The statement is declared reliable if Cronbach's Alpha $>0.5$. Based on the data above, Cronbach's Alpha for all aspects (economics, social, and environmental aspects) are reliable. Cronbach's Alpha of economics aspect is 0.606; social is 0.778 ; and environmental aspect is 0.853 . 


\section{Frequency and Descriptive (Mean) Analysis}

Frequency analysis on gender of 92 respondents is shown that male is $46.7 \%$ and female is $53.3 \%$. According to ages, the respondents at the age of 17 up to 25 years old is $10.9 \%$; 26 up to 35 years old is $21.7 \%$; 36 up to 45 years old is $42.4 \%$; and more than 45 years old is $25 \%$. Based on the job, farmers are $31.5 \%$; Construction workers are 5.4\%; Street vendors are 57.6; and employees are $5.4 \%$. The respondent's jobs are $31,5 \%$ as farmers; $5.4 \%$ as contraction worker; $57.6 \%$ as street vendors; and $5.4 \%$ as employees.

Table 2. Frequency Analysis

\begin{tabular}{llr}
\hline Respondents' Profile & & Percent \\
\hline Gender & Male & 46.7 \\
& Female & 53.3 \\
\hline Ages & 17-25 years old & 10.9 \\
& 26-35 years old & 21.7 \\
& 36-45 years old & 42.4 \\
& $>45$ years old & 25 \\
\hline Jobs & Farmer & 31.5 \\
& Construction worker & 5.4 \\
& Street vendors & 57.6 \\
& Employee & 5.4 \\
\hline Education background & Elementary school & 44.6 \\
& Junior high school & 34.8 \\
& Senior high school & 18.5 \\
& Bachelor degree & 2.2 \\
\hline Income per month & <IDR 1 million & 38 \\
& IDR 1-2 million & 43.5 \\
& IDR 2-3 million & 16.3 \\
& >IDR 3 million & 2.2 \\
\hline
\end{tabular}

Their educational backgrounds are 44.6\% elementary school; 34.8\% junior high school; $18.5 \%$ senior high school; and 2.2\% bachelor degree. The respondent's income per month are 38\% less than 1 million IDR; $43.5 \% 1$ up to 2 million IDR; $16.3 \% 2$ up to 3 million IDR; and 2.2\% more than 3 million IDR. Table 2 describes the frequency analysis of respondents clearly.

Frequencies analysis of economics, social, and environmental aspects as described in table 3. In the point of economics aspect most of the respondents 'agree' that Wanayasa tourism destination development (1) provides job opportunity for Sumurugul village society (84.8\%); (2) increases Sumurugul society income $(75.0 \%)$; (3) provides an opportunity for the community to sell their creations $(82.6 \%)$; and (4) improves transportation facilities $(81.5 \%)$. But most of the respondents say 'neutral' that Wanayasa tourism destination development makes the price of goods and services cheaper. In the point of social aspect most of the respondents 'agree' that Wanayasa tourism destination development (1) improves society welfare (67.4\%); (2) impacts local culture positively (60.9\%); (3) impacts society understanding of other area habits (73.9\%); (4) changes the society mindset become more modern (76.1\%); (5) changes the society habits in interacting to visitors $(70.7 \%)$. For environmental 
aspect, most of the respondents say 'agree' that Wanayasa tourism development doen't cause (1) an environment full of garbage (64.1\%); (2) vandalism $(70.7 \%)$; (3) air pollution (57.6\%); (4) noise pollution (42.4\%); (5) water pollution $(66.3 \%)$; (6) public spaces narrowing (62\%); (7) plants and trees damaged (76.1\%); (8) running the beauty of sceneries $(44.6 \%)$.

Descriptive (mean) analysis found that respondents think Wanayasa tourism development affects social aspect at most (mean 3.93). It's followed by economics aspect (mean 3.90) and environmental aspect (mean 3.68).

Table 3. Frequencies and Mean of Perception Analysis in The Point of

\begin{tabular}{|c|c|c|c|c|c|c|}
\hline Perception variables & $\begin{array}{l}\text { Strongly } \\
\text { disagree }\end{array}$ & Disagree & Neutral & Agree & $\begin{array}{l}\text { Strongly } \\
\text { agree }\end{array}$ & Mean \\
\hline $\begin{array}{l}\text { Economics: Wanayasa tourism } \\
\text { destination development }\end{array}$ & & & & & & 3.90 \\
\hline $\begin{array}{l}\text { 1. provides job opportunity for } \\
\text { Sumurugul village society }\end{array}$ & $0 \%$ & $3.3 \%$ & $3.3 \%$ & $84.8 \%$ & $8.7 \%$ & 3.99 \\
\hline $\begin{array}{l}\text { 2. increases Sumurugul society } \\
\text { income }\end{array}$ & $0 \%$ & $6.5 \%$ & $7.6 \%$ & $75.0 \%$ & $10.9 \%$ & 3.90 \\
\hline $\begin{array}{l}\text { 3. provides an opportunity for } \\
\text { the community to sell their } \\
\text { creations }\end{array}$ & $0 \%$ & $5.4 \%$ & $2.2 \%$ & $82.6 \%$ & $9.8 \%$ & 3.97 \\
\hline $\begin{array}{l}\text { 4. improves transportation } \\
\text { facilities }\end{array}$ & $0 \%$ & $0 \%$ & $5.4 \%$ & $81.5 \%$ & $3.0 \%$ & 4.08 \\
\hline $\begin{array}{l}\text { 5. makes the prices of goods } \\
\text { and services cheaper }\end{array}$ & $0 \%$ & $17.4 \%$ & $54.3 \%$ & $25.0 \%$ & $3.3 \%$ & 3.14 \\
\hline $\begin{array}{l}\text { Social: W anayasa tourism destination } \\
\text { development }\end{array}$ & & & & & & 3.93 \\
\hline 1. improves society welfare & $0 \%$ & $0 \%$ & $20.7 \%$ & $67.4 \%$ & $12.0 \%$ & 3.91 \\
\hline $\begin{array}{l}\text { 2. impacts society culture } \\
\text { positively }\end{array}$ & $0 \%$ & $5.4 \%$ & $28.3 \%$ & $60.9 \%$ & $5.4 \%$ & 3.66 \\
\hline $\begin{array}{l}\text { 3. impacts society } \\
\text { understanding of other area } \\
\text { habits }\end{array}$ & $0 \%$ & $0 \%$ & $20.7 \%$ & $73.9 \%$ & $5.4 \%$ & 3.85 \\
\hline $\begin{array}{l}\text { 4. changes the society mindset } \\
\text { become more modern }\end{array}$ & $0 \%$ & $0 \%$ & $13.0 \%$ & $73.9 \%$ & $13.0 \%$ & 4.00 \\
\hline $\begin{array}{l}\text { 5. changes the society used to } \\
\text { interacting with visitors }\end{array}$ & $0 \%$ & $2.2 \%$ & $15.2 \%$ & $76.1 \%$ & $6.5 \%$ & 3.87 \\
\hline $\begin{array}{l}\text { 6. changes the society habits in } \\
\text { interacting to visitors }\end{array}$ & $0 \%$ & $2.2 \%$ & $13.0 \%$ & $70.7 \%$ & $14.1 \%$ & 3.97 \\
\hline $\begin{array}{l}\text { Environmental: W anayasa tourism } \\
\text { destination development doesn't cause }\end{array}$ & & & & & & 3.68 \\
\hline $\begin{array}{l}\text { 1. an environment full of } \\
\text { garbage }\end{array}$ & $4.3 \%$ & $15.2 \%$ & $14.1 \%$ & $64.1 \%$ & $2.2 \%$ & 3.45 \\
\hline 2. vandalism & $1.1 \%$ & $15.2 \%$ & $10.9 \%$ & $70.7 \%$ & $2.2 \%$ & 3.58 \\
\hline 3. air pollution & $1.1 \%$ & $18.5 \%$ & $19.6 \%$ & $57.6 \%$ & $3.3 \%$ & 3.43 \\
\hline 4. noise pollution & $3.3 \%$ & $14.1 \%$ & $37 \%$ & $42.4 \%$ & $3.3 \%$ & 3.28 \\
\hline 5. water pollution & $3.3 \%$ & $3.13 \%$ & $10.9 \%$ & $66.3 \%$ & $6.5 \%$ & 3.60 \\
\hline 6. public spaces narrowing & $2.2 \%$ & $13.0 \%$ & $15.2 \%$ & $62.0 \%$ & $7.6 \%$ & 3.60 \\
\hline 7. plants \& tress damaged & $0 \%$ & $8.7 \%$ & $6.5 \%$ & $76.1 \%$ & $8.7 \%$ & 3.85 \\
\hline $\begin{array}{l}\text { 8. ruining the beauty of } \\
\text { sceneries }\end{array}$ & $0 \%$ & $2.2 \%$ & $22.8 \%$ & $44.6 \%$ & $30.4 \%$ & 4.03 \\
\hline
\end{tabular}


Those implied that respondents had perceptions that Wanayasa tourism development affected economics, social, and environmental aspect on Sumurugul village society. For economics aspect, they thought "Wanayasa tourism development improves transportation facilities" (mean 4.08); but they thought neutral that "Wanayasa tourism development makes the prices of goods and services cheaper". The last statement implied that the price at Sumurugul village might be expensive after Wanayasa tourism development. For social aspect, the respondents thought that "Wanayasa tourism development changes the society mindset become more modern" (mean 4.00). It implied that Wanayasa tourism destination development affected the society mindset become more modern. The lowest mean of social aspect was "Wanayasa tourism development impacts society culture positively" (mean 3.66). It implied that Wanayasa tourism destination development affected society culture positively. In the point of environmental aspect, respondents answer the highest for the statement of "ruining the beauty of sceneries" (mean 4.03). It implied that Wanayasa tourism destination development does't ruining the beauty of sceneries. Moreover, respondents answer the lowest for the statement of "Wanayasa tourism destination development doesn't cause noise pollution" (mean 3.28). It implied that Wanayasa tourism destination development didn't affect noise pollution.

\section{E. Discussion}

In the point of economics aspect, the respondents 'agree' that there are job opportunity, income improvement, and opportunity for selling their products (such as souvenirs), and transportation facilities improvement. It's implied that Wanayasa tourism destination development will be welcomed by the society because its development drove local society economic level (Aldila, 2012; Hariyana et al., 2012) such as creating job opportunity (Hamzah et al., 2018), having better income (Ningsih et al., 2018), and entrepreneurship activities growth (Subchan, 2014), and better transportation availability (Li, S.N., 2017). In another word, tourism activities generates economic added value for local society and implement pro-poor policy (Vitriani et al., 2018). The consequences of tourist destination development caused the price of goods and services tended to be expensive. This condition was streghthen the previous study which found goods and services tend to be higher while tourism activity was completed (P.D. Pramanik \& Ingkadijaya, 2017).

For social aspect most of the respondents 'agree' that Wanayasa tourism destination development (1) improves society welfare; (2) impacts local culture positively; (3) impacts society understanding of other area habits; (4) changes the society mindset become more modern; (5) changes the society habits in interacting to visitors. The study result found that Wanayasa tourism destination 
development improves social and individual well-being (Choi, 2005). In this case tourism has positive impact.

For environmental aspect, most of the respondents say 'agree' that Wanayasa tourism development doen't cause (1) an environment full of garbage; (2) vandalism; (3) air pollution; (4) noise pollution; (5) water pollution; (6) public spaces narrowing; (7) plants and trees damaged; (8) running the beauty of sceneries. It's concludes that there is the positive impacts on environmental aspect because the tourism activities preserve cleaner communal area, and an improvement of public service (Asyraf, 2017). It found that tourism activities is able to reduce the negative impacts on the environment (Choi, 2005) such as an increase of pollution levels on air, water, and noise (Garau-Vadell et al., 2018).

Descriptive (mean) analysis found that respondents think Wanayasa tourism development affects social, economics, and environmental aspect. For economics aspect, they thought "Wanayasa tourism development improves transportation facilities". This situation is related to the previous study that tourism activities improves local transportation providers (Hamzah et al., 2018). But they thought neutral that "Wanayasa tourism development makes the prices of goods and services cheaper". The last statement implied that the price at Sumurugul village might be expensive after Wanayasa tourism destination development, which was also found at the study in Pasir Angin Village (P.D. Pramanik \& Ingkadijaya, 2017).

For social aspect, the respondents thought that "Wanayasa tourism development changes the society mindset become more modern". The lowest mean of social aspect was "Wanayasa tourism development impacts society culture positively". The respondents answer the highest for the statement of "ruining the beauty of sceneries". Moreover, respondents answer the lowest for the statement of "Wanayasa tourism destination development doesn't cause noise pollution". Those descriptions are opposite to the previous study that the quality of the nature could deteriorate as the result of human activities at tourism destination (Asyraf, 2017). There aren't any negative impacts such as an increase of pollution levels on air, water, and noise (Garau-Vadell et al., 2018). It's shown that tourism activities at Wanayasa have reduced the negative impacts on the environment (Choi, 2005).

\section{F. Conclusion}

Wanayasa tourism destination development contributes positive impacts on economics, social, and environmental aspect for Sumurugul village society as the local community. This study will bring to the conclusion that Wanayasa tourism destination development is welcomed by local society. This situation is good in the point of sustainable tourism. 


\section{G. Acknowledgement}

We appreciate to Ministry of Research, Technology and Higher Education and Sekolah Tinggi Pariwisata Trisakti that have facilitated us to do research in Sumurugul village, West Java, Indonesia.

\section{REFERENCES}

Aldilla, Adelia. (2012). Persepsi Masyarakat terhadap Pengembangan Kawasan Eko Wisata Islami Curug Cigangsa (Kasus: Kampung Batusubunan, kelurahan Surade, kabupaten Sukabumi, propinsi Jawa Barat). Skripsi. Departemen Sains Komunikasi dan Pengembangan Masyarakat Fakultas Ekologi Manusia, Institut Pertanian Bogor.

Asyraf, A., Zainudin, A., and Sharifah,F.(2017).Perception of Tourism Impact and Support Tourism Development in Terengganu, Malaysia.MPDI Social Sciences Journal,Vol.6.

Choi, Hwan-Suk Chris and Sirakaya, Ercan.(2005).Measuring Residents' Attitude toward Sustainable Tourism: Development of Sustainable Tourism Attitude Scale. University of South Carolina, Journal of Travel Research, Vol.43.

Garau-Vadell, J.B., Gutierrez-Taho D., and Diaz-Armas R. (2018).Economic Crisis and Residents' Perception of the Impacts of Tourism in Mass Tourism Destinations. Elsevier, Journal of Destination Marketing \& Management, Vol.7.

Hamzah, F., Hermawan, H., and Wigati. (2018). Evaluasi Dampak Pariwisata terhadap Sosial Ekonomi Masyarakat Lokal. Universitas BSI Bandung: Jurnal Pariwisata, Vol.5(3).

Hanafiah, M.H., Inoormaziah,A., Jamaluddin,M.R., Amnuddin,N.(2016).Responsible Tourism Practices and Quality of Life:Perspective of Langkawi Island Communities.Elsevier,Social Behavioral Sciences, Vol.222,406-413.

Hariyana, I Kadek and Oka, I Gst. Agung.(2015). Persepsi Masyarakat terhadap Pengembangan Kawasan Goa Peteng sebagai Daya Tarik Wisata di Desa Jimbaran Kuta Selatan Kabupaten Badung. Jurnal Destinasi Pariwisata, vol.3, no.1.

Li S.N., Song H., L Lunberg C., and Shen S.(2017).The Economic Impact of on- Screen Tourism: The Case of the Lord of the Rings and Hobbit. Journal Tourism Management, Vol.60.

Ningsih, Ni Wayan A.S., and Suryasih, Ida Ayu. (2018). Dampak Sosial Ekonomi Pariwisata Pariwisata terhadap Pedagang Souvenir di Daya Tarik Wisata Pura Gunung Kawi Tampak Siring Gianyar. Universitas Udayana: Jurnal Destinasi Pariwisata, Vol. 6(1), 2018. 
P.D. Pramanik \& Ingkadijaya. (2017). The Impact of Tourism on Village Society and Its Environment. 1st UPI International Geography Seminar 2017 IOP Publishing. IOP Conf. Series: Earth and Environmental Science 145 (2018) 012060 doi :10.1088/1755-1315/145/1/012060.

Postma Albert., Cavagnaro Elena, Spruyto Ernesto.(2017).Sustainable Tourism 2040. Journal of Tourism Future, Vol.3(1).

Pratt, Stephen.(2015).The Economic Impact of Tourism in SIDS.Elsevier, Annals of Tourism Research, Vol.52,148.

Reisinger, Yvette.(2001). Service Quality Management in Hospitality, Tourism, and Leisure. Editors: Kandampully, Jay., Mok, Connie, \& Sparks, Beverley. New York: Routledge.

Ritchie, J.R. Brent \& Crouch, I. Geoffrey.(2003). The Competitive Destination: A Sustainable Tourism Perspective. Canada: CABI Publishing.

Robbins, Stephen P.(1998).International Edition: Concepts, Controversies, and Application Organizational Behavior. New Jersey: Prentice-Hall International, Inc.

Subchan.(2014).Dampak Pariwisata terhadap Ekonomi Masyarakat di Kecamatan Matur Kabupaten Adam. Thesis: Universitas Andalas.

Sudarmayasa, I Wayan, and Nala, I Wayan L.(2019). Dampak Keberadaan Sektor Pariwisata terhadap Peningkatan Faktor Sosial Ekonomi Masyarakat Kampung Tenun Samarinda d Kota Samarinda Kalimantan Timur. JUMPA, Vol.05(02).

Swarbrooke, John.(2002). The Development ang Management of Visitor Attractios. United Kingdom: Reed Educational and Professional Publishing Ltd.

Vitriani, C., Sudibyo, D., \& Hermantoro, H. (2017). Socio-Economic Impacts of Tourism Development in Rural Area of Sembalun East Lombok West Nusa Tenggara. TRJ Tourism Research Journal, 1(1), 1-21.

Wang Yi-Ping.(2016).A Study on Kinmen Resident's Perception of Tourism Development and Culture Heritage Impact. Eurasia Journal of Mathematics, Science \& Technology Education, Vol.12(12),2909. 